\title{
Manufacturing Germans: Singer Manufacturing Company and American Capitalism in the Russian Imagination during World War I
}

\author{
BENJAMIN SAWYER
}

Just months after the outbreak of World War I, rumors spread throughout the Russian Empire that Singer Manufacturing Company's wholly owned Russian subsidiary, Kompaniia Zinger, was a German company that was actively engaged in espionage on behalf of the German military. Even though these rumors were untrue, they unleashed a wave of actions against the company that Singer's officials were unable to stop, ultimately leading to tremendous losses for the firm. The central argument of this article is that the power of the accusations of Singer's German ties rested far more on the nature of the company's business model than on the national affiliation of its personnel or evidence of espionage. In the context of World War I-era Russia, many Russians took Singer's operations not as those of an international capitalist enterprise, but rather as evidence of the company's questionable foreign character. This perspective helps us to understand why Singer's management had such difficulty shaking the accusations of its German ties; if what was suspicious about the company was the very foundation of its business model, then its continued operation meant that it necessarily exhibited characteristics that reinforced the basis for said suspicion. These findings have implications for international business history, the history of late-Tsarist Russia, and the history of capitalism.

C The Author 2016. Published by Cambridge University Press on behalf of the Business History Conference.

doi:10.1017/eso.2015.71

Published online January 22, 2016

Benjamin Sawyer is a lecturer in the Department of History at Middle Tennessee State University. Contact information: Box 23, 1301 E. Main St., Murfreesboro, TN 37132. E-mail: Benjamin.Sawyer@mtsu.edu.

The author would like to thank Lewis Siegelbaum, Sayuri Shimizu, Kelly Kolar, Rohan Kalyan, and Jeremy Sather for their help in writing and revising this article. The author is also indebted to Andrew Popp and the three anonymous reviewers at Enterprise \& Society who gave outstanding feedback on this work. Research for this article was supported by a Milton Muelder Fellowship (Michigan State University). 
On November 12, 1914, just a few months after the outbreak of World War I, a letter from S. Levitskii, a disgruntled ex-employee of Singer Manufacturing Company's Russian subsidiary, Kompaniia Singer (KS), arrived at the company's headquarters in Moscow. Levitskii, the former manager of a depot in Tula Oblast, asked company officials to drop the embezzlement charges they had brought against him and reinstate him in his former position. Clearly unconvinced that his request would be fulfilled through the good graces of the company's management alone, Levitskii supplemented his request with an announcement that he was in possession of proof that Singer was a German company that was actively engaged in espionage against the Russian Empire. Perhaps because these claims were false or because this was not Levitskii's first blackmail attempt, company officials chose to do as they had before-ignore his threats. This time, though, Levitskii made good on his word, and in the following months his "evidence" surfaced in Russian newspapers. At about the same time, speculation about Singer's questionable loyalties was spreading across Russia, causing the military to shut down Singer's offices and convincing some of the highest echelons of the Russian state that Singer was worthy of supervision. The series of events that followed the proliferation of this rumor eventually led Singer's American managers to lose hope in what had, just a few years earlier, become its largest foreign market.

The relationship of this rumor to Singer's fate in Russia has gone almost unmentioned in the few works of business history that focus on the company. ${ }^{1}$ Such an omission is not surprising; like much traditional business history, these works focus on the operation of the company and organizational strategy, and not so much on the nuances of the local cultures in which the company operated. Recently, Russian historians have given limited attention to Singer's Russian operations during World War I. Christine Ruane's The Empire's New Clothes provides the most extensive account of Singer's plight during that war. Ruane points to Levitskii's blackmail attempts and the interest that those in Russian business circles had in seeing Singer removed from

1. Perhaps the most well-known work of business history on Singer's Russian operations is Carstensen, Enterprise, which concludes in 1914, and gives no attention to World War I aside from a single reference that the tsarist government placed KS under supervision because of fears that it was a German company. However, Carstensen follows that it "took some time for Singer management to convince government officials that the enterprise was in fact American," (Cartensen, Enterprise, 80). A second work on Singer's operations is Davies, Peacefully. This work is much more general than Carstensen's and covers Singer's presence in other foreign markets, such as India, China, and Turkey, but Davies gives more attention to Russia than to any other country. In both cases, the focus of the work remains the company and the decision makers within it, with little interest in the local culture. 
the Russian market, as well as "just how elastic the category of 'German' had become” during the war. ${ }^{2}$ Eric Lohr's and William C. Fuller's works on World War I-era Russia briefly address Singer's plight during the war, with both presenting the move to sequester the company as driven by the Russian military and its accusations that the company was engaged in espionage. ${ }^{3}$ As such, these authors suggest that the majority of Singer's troubles began with the military sequestration of Singer's offices that took place in the summer and early fall of 1915. Although these works do well to identify incentives for the pursuit of Singer, they fail to account for the reasons that these accusations were so well received by the general population of Russia. The most recent work on this question, Mona Domosh's "Uncovering the Friction of Globalization: American Commercial Embeddedness and Landscape in Revolutionary-Era Russia," is correct in its assessment that local context is essential to understanding the differing outcomes of foreign businesses in Russia at this time, but Domosh's thin understanding of Russian history limits her ability to reach new conclusions about Singer's experiences in Russia. ${ }^{4}$

The central argument of this article is that the power of the accusations of Singer's German ties rested far more on the nature of the company's business model than on the national affiliation of its personnel or any evidence that the company was engaged in espionage against the Russian Empire. In the context of World War I-era Russia, many Russians took Singer's unique operations not as those of a rationalized modern capitalist enterprise, but rather as evidence of the company's questionable foreign character. This perspective helps us to understand why Singer's management had such difficulty shaking the accusations of its German ties; if what was suspicious about the company was the very foundation of its business model, then its continued operation meant that it necessarily exhibited characteristics that reinforced the basis for said suspicion. This article also sheds light on the reasons that the Russian public's suspicion of the firm

2. Ruane, Clothes, 230.

3. Lohr, Nationalizing, 80; Fuller, Foe.

4. Domosh, "Uncovering." Domosh is to be commended for pointing out that Singer and International Harvester's differing outcomes "were based as much on the "local" Russian actions as they were on decisions made by U.S. executives" (429), but she lacks the professional background and language skills required to offer any substantial new insight into the local conditions that she seeks to elucidate. Although most of her assertions are correct, her understanding of Russian society during World War I relies almost exclusively on the works of a few experts on Russian history, leading her to replicate their blind spots in her own work. Domosh does, however, do a good job of using the available data to reach conclusions about the differing outcomes seen by Singer and International Harvester during and after World War I. 
both predated and postdated the official state and military actions against Singer in 1915.

\section{Singer's History in Russia}

Singer's entry into the Russian Empire came as part of its greater international expansion in the second half of the nineteenth century. Although its first contact with the Russian market occurred as early as 1865, Singer's Russian operations were carried out through its German office until the 1890s, when a combination of saturated markets in Western Europe and growing sales in Russia made operating in the empire look far more appealing than it had in previous years. ${ }^{5}$ After considering several options, company officials decided that the most effective way to secure a foothold in the Russian market would be to establish a wholly owned subsidiary that was incorporated under Russian law. ${ }^{6}$ Formal measures to obtain this status began in late July 1896, and in June 1897 Singer received approval from the Russian government for the establishment of Kompaniia Singer (KS).

Although Singer was one of the first American companies to realize the potential of the Russian market, it was only one of numerous foreign firms to establish a presence in the Russian Empire at the turn of the century. By 1914, foreign firms accounted for 262, or 11 percent, of the 2,380 corporations operating within the Russian Empire. ${ }^{7}$ Among these were some of the most powerful companies in Russia, including International Harvester and New York Life.

The process for incorporation in Imperial Russia was a complicated affair that required the tsar himself to personally approve any petition for a charter. As a part of their effort to gain the favor of Nicholas II and other Russian bureaucrats, Singer officials' request for incorporation included a promise to establish a production facility inside Russian borders. This decision, described by one scholar as evidence of "the maturation of the of the firm's political education,"

5. The improvements in the business climate came from a number of developments, including rising household income, railroad construction that opened new markets, and new restrictions on the state's ability to interfere with businesses that were promoted by Sergei Witte following his appointment as Minister of Finance in 1892. Although Witte never pushed for the complete abolition of governmental privilege in corporate charters, his outspoken opposition to restrictions on non-Russian ownership of corporations must have certainly looked like a positive development to foreigners who were interested in investing in the Russian Empire. For more on corporations in Russia at this time, see Owen, Corporation.

6. Davies, Peacefully, 246-248. Singer officials also considered opening Russian branch offices of either their New York or German companies.

7. Owen, Corporation, xiv. 
was meant to appeal to decision makers inside the Russian Ministry of Finance who were attempting to attract more foreign capital into the Russian Empire. ${ }^{8}$ After a year of searching, economic and political conditions led the company to purchase eighty-one acres of land twenty-six miles south of Moscow, in the town of Podolsk. Russian officials approved the sale of this land in October 1899 and, in 1902, Singer's Podolsk factory officially opened.

From a distance, Singer's decision to open a wholly owned subsidiary in Russia appears to run contrary to the theoretical literature on international entry mode. The low governance quality of the tsarist regime, with its concentrated power and lack of a clear long-term economic strategy, offered a high degree of external uncertainty, yet Singer's officials never seriously considered a joint venture as means of mitigating their risk. ${ }^{9}$ This, as Andrew Godley has done well to show, was because Singer's success abroad came from the company's selling organization. Thus, to choose other entry modes was to increase the internal risk that Russian offices might stray from the organizational model that was key to Singer's success. ${ }^{10}$ In addition, the potential gains that could theoretically apply in the selection of a joint venture or licensing entry mode did not apply to the case of Singer. Because the company did not interact with the Russian government beyond that which was required to gain incorporation and purchase land, Singer's officials must have seen little benefit in securing local allies in the 1890s. Furthermore, the fact that Singer's success was based on its market-making organizational strategy and not on technological innovation meant that the risk of dissemination of know-how was not a driving factor in its choice of a wholly owned subsidiary. ${ }^{11}$ In light of these considerations, as well as the fact that Singer had seen success in other markets without surrendering influence to local partners, Singer's choice of entry mode was a rational decision for Singer's managers in the 1890s.

8. Davies, Peacefully, 249.

9. Of the six categories proposed by Slangen and Tulder to gauge governmental quality, Russia certainly ranked low in terms of voice and accountability, government effectiveness, regulatory quality, and rule of law. Singer's perception of the other categories, control of corruption and government stability, may, however, have been less dismal. In regard to the former, Carstensen has pointed out that Singer's papers give no indication that there were issues with the "presumed venality of Russian bureaucrats and the allegedly low level of commercial honesty" (Carstensen, Enterprise, 101). In terms of the latter, which Slangen and Tulder identify as the weakest factor in determining entry mode decisions, the nearly 300-year reign of the Romanov dynasty must have certainly convinced Singer's officials of the high stability of the Russian government in the 1890s. Unfortunately for the company, their assessment of this category turned out to be quite wrong (Slangen and Tulder, "Cultural Distance”).

10. Godley, "Selling;" Godley, "Entrepreneurial."

11. Hill, Hwang, and Kim, "Eclectic Entry." 
Singer's basic organizational model involved offering consumers the opportunity to purchase sewing machines on installment plans, as well as the development of large numbers of local offices, each of which was intimately responsible for the company's business in a relatively small portion of a given market. The local offices consisted of management and office staff, as well as canvassers who were responsible for demonstrating products and making sales, and collection agents who were responsible for making weekly visits to the homes of those who had purchased the machines through installment plans. ${ }^{12}$ The oversight built into this model was an effective means of reducing the risk of embezzlement, but the inability of smaller rural offices to support so many workers often meant that in Russia, one worker often carried out multiple functions. ${ }^{13}$

The application of Singer's organizational model to the Russian market, if altered somewhat to meet local conditions, quickly proved to be a success. Sewing machines were desired labor-saving devices by families across the globe, and Singer's aggressive sales policies, which included making contact with regions that were otherwise isolated from established sales networks, meant that Singer had access to a wider market than its competitors. These market-making innovations helped Singer's sales in Russia to grow tremendously, from 68,788 machines prior to the establishment of KS in 1895 to 678,989 machines in 1914. Thus, by the beginning of World War I, Russia had become Singer's second largest market, with first-quarter sales positioning KS to beat out even the American market by the end of the year. ${ }^{14}$

As a means of better understanding the relationship of Levitskii's assertions to fact, it is worth addressing Singer's actual German ties on the eve of World War I. It is true that Singer's entry into the Russian market had come through its German office, and the company had long relied on foreign nationals and ethnic minorities within the country to fill its management positions. At the outbreak of World War I, one of Singer's board members was Albert Flohr, a German national who had held his position since 1902 and continued to play a role in Singer's Russian operations at the beginning of 1914. Of those employed in KS's offices, company records show that 13 of the 40 employees in its main office in Moscow, and 112 of its managers and assistant managers "in the provinces in the Central and sub-branches," were subjects of the countries that were Russian enemies in World War I.

12. Davies, "Peacefully Working," 307.

13. Godley, "Selling," 287. By the 1890s, half of Singer's Russian salesmen operated in these rural areas.

14. Carstensen, Enterprise, 69-71. 
Thus, although these individuals made up a small minority of the company's approximately more than 24,000 sales personnel, they did hold some of the most important positions in the company. ${ }^{15}$ In its Podolsk factory, which was headed by U.S. national Walter Dixon, the company reported that four of its 567 staff employees and two of its 4,154 factory workers were German nationals, making it possible that 131 of its 29,435 Russian employees in 1914 were of enemy nationalities. ${ }^{16}$

It is also worth noting that Singer did have an unfortunate disadvantage working against it when Russians began to suspect German activity within the empire: In the company's transliteration of the name "Singer," it had adopted a Russian "z" (3) instead of a Russian "s" (C), making the pronunciation "Kompaniia Zinger" (Компанія Зингеръ). This minor decision had the effect of making the company's name sound more like a German name to Russians than an American one. Although some evidence indicates that many Russians were aware that the company was (at least ostensibly) American, it seems that this was "forgotten" by at least some of the many Russians who became convinced of the company's German ties following the onset of the war. ${ }^{17}$

When World War I broke out, Russians, much like their counterparts in other European countries, responded with an outburst of patriotism and popular support for the war. This was accompanied by intense anti-German sentiment at all levels of Russian society. Just days after the outbreak of the war, in August 1914, workers at the Kharkov Locomotive Works waged an effective strike aimed at the dismissal of all German and Austrian supervisors employed in the works. This was followed by increasingly frequent calls for the seizure and redistribution of German-held assets and the expulsion of all enemy nationals from Russian soil. ${ }^{18}$ The Russian government responded to this concern with a series of laws in 1915 that required the liquidation of any trading firm or corporation in which German citizens held majority interests. ${ }^{19}$

15. These numbers do not include those who had become Russian subjects, or employees from Russia's Volga and Baltic German populations. Carstensen, Enterprise, 80.

16. Notes from the first meeting of the Commission of Representatives of the All-Russian Zemstvo and Town Association, August 8, 1915, Box 155, Folder 1, Singer Manufacturing Company Records 1850-1975, Wisconsin Historical Society.

17. A few years earlier, Singer had faced problems selling its Russian-made machines to Russians, many of whom felt that Russian workers were incapable of making products that were as high in quality as their American counterparts. Carstensen, Enterprise, 83.

18. Gatrell, War, 180.

19. Owen, Corporation, 182. 


\section{The Levitskii Case}

Such was the climate in Russia when, on November 8, 1914, Singer's officials accused S. Levitskii of embezzling 460 rubles, and promptly fired him from his job as a depot manager in the town of Aleksin, located about 85 miles south of Moscow in Tula Guberniia. Hoping to clear his name and resume his employment, Levitskii responded the very same day by writing directly to Singer board member Albert Flohr, claiming that he was innocent of the crime. ${ }^{20}$ In his letter, Levitskii noted the excellent performance of the shop in his tenure as its manager, and assured Flohr that he had evidence of his innocence, asking that the company "investigate this matter and defend [him]." Hoping to encourage Flohr to listen to his side of the story, Levitskii followed by adding that he was aware of company operations that would result in more than 4 million rubles' worth of fines for the company. This matter, he explained, is "of no interest to me," adding that "if you will do justice in my case then I shall not move in this matter but shall keep quiet ... as it is none of my business." Levitskii closed his letter by stating that if he did not receive a reply by November 10, he would be forced to "defend [himself] by all permissible means and lawful measures." 21 Company officials chose to ignore the letter and never responded to Levitskii.

20. Notes from the first meeting of the Commission of Representatives of the All-Russian Zemstvo and Town Association, August 8, 1915, Box155, Folder 1, Singer Manufacturing Company Records 1850-1975, Wisconsin Historical Society. According to Carstensen, instances of embezzlement became much more prevalent just before World War I, a phenomenon he attributes to the inability of the company to produce enough machines for their shops to sell (Carstensen, Enterprise, 88-89).

21. Levitskii to Flohr, August 8, 1914, Box 155, Folder 1, Singer Manufacturing Company Records 1850-1975, Wisconsin Historical Society. The documents that are being examined here were translated into English by the company for its files, and all quotations used here, including any incorrectly spelled words within them, are from these translations. As a result, I have chosen not to include the emphasis on several words that were typed in all capital letters, as there is no indication as to whether this emphasis was Levitskii's or that of the translator, who wished to draw attention to certain phrases for internal purposes.

The Singer records hold extensive papers relating to the company's operations across the globe, and offer tremendous insight into the local conditions in which they operated. The company's records certainly reflect the biases of company officials and are shaped by their interests; however, Singer's correspondence with those outside the company during World War I is consistent with internal correspondence. Furthermore, these papers demonstrate officials' desire to gather and consider all possible information on issues, and had they uncovered evidence of actual espionage within their offices, there is little reason to suspect that they would have sought to cover it up.

Singer's account is also substantiated in the records of the Finnish Gendarmerie, which was tasked with investigating the activities of Singer's offices in Finland (then a part of the Russian Empire) in July and August 1915. These papers 
Four days later, a second letter from Levitskii arrived in Singer's Moscow office, this time addressed to the company's personnel at large. The tone of this letter was markedly different from his first, and cut straight to his threats against the company. Levitskii reiterated his previous claims against Singer, but this time enclosed a second document that leveled a far more lethal blow to the company's credibility: the claim that KS was a German organization that was as interested in producing intelligence for the German military as it was in producing sewing machines. Concerned that such accusations might endanger his life, Levitskii added that he had given a copy of the enclosed document to an anonymous third party who, if not given instructions from Levitskii in three days, would send this copy to a number of addresses, including those of the Russian Minister of Interior, the Minister of Finance, and "two of the most well circulated newspapers.” In concluding his letter, Levitskii stated his dedication to pursuing this matter and briefly appealed to the humanity of his former employers, stating that he was "unexpectedly, in the middle of winter, thrown with [his] family on the streets without any means, and, in addition, disgraced." 22 Just as before, the company chose to ignore Levitskii's letter. Though clearly a fabrication, the text of Levitskii's document provides significant insight into the anxieties that many Russians felt in their early engagement with a rationalized capitalist enterprise.

The text of Levitskii's enclosed document did not begin with a direct accusation, but instead coyly treated German espionage as a mere possibility. Even though he never mentioned the name of the company directly, Levitskii was quick to establish the target of his supposition by noting that this firm had, for many years, been selling its products within Russia "almost exclusively on installments." 23 Since the 1870s, he stated, this company, "like an enormous sea-serpent," had wrapped its tentacles over the entire empire, sucking the life out of Russia, as unwitting citizens continued to "reward [the company]

demonstrate that government officials in Finland found no evidence of espionage by Singer's officials in the region, but in some cases, local police officers arrested and held Singer employees until ordered to release them by their superiors (Fond 494, Opis 2, Delo 94, "Correspondence with the Head of the Finnish Gendarmerie on the Search and Arrest of Employees of Kompaniia 'Zinger' Suspected of Spying for Germany," State Archives of the Russian Federation).

22. Levitskii to Singer, August 12, 1914, Box 155, Folder 1, Singer Manufacturing Company Records 1850-1975, Wisconsin Historical Society. Ruane has pointed out the emergence of many of Levitskii's accusations in the press, although she does not note that they were drawn directly from Levitskii's letter. (Ruane, Clothes, 328-331.)

23. Levitskii to Singer, August 12, 1914, Box 155, Folder 1, Singer Manufacturing Company Records 1850-1975, Wisconsin Historical Society. All subsequent consecutive quotations come from this document. 
afterwards with blood-earned gold and silver, which it even divides with its comrades abroad." Thus, Levitskii opened his letter by linking the structure of KS, as a subsidiary of a foreign corporation, to an extraction process that was funneling Russian wealth and resources abroad.

Next, Levitskii questioned the motives behind the company's relocation of its central office from St. Petersburg to Moscow in 1911, a move he implied would make no sense unless its operators found this "central position" to be more in line with the "objects of the firm," with these "objects" left to the reader's imagination. Both this accusation and the one that preceded it seem to be aimed at stoking the anxieties and perplexity that Russians may have felt in their first encounters with modern business practices. Here, installment plans (finance) and the ease with which the company could relocate (mobility), two defining characteristics of modern capitalist enterprise, were presented as evidence of the questionable nature of the company itself.

Levitskii followed these points by directing his attention to the organization of Singer's sales network within Russia. After a brief explanation of the establishment of Singer's districts within Russia, Levitskii turned to the activities of Singer's sales operatives. He explained that at the lowest (volost) level, these managers traveled the Russian countryside "ostensibly selling goods and receiving money from the customers." Thus, Levitskii noted with a bit of exaggeration, "there is not one small village over the whole surface of our boundless Russia which is not visited, even if only once a month, by agents of the firm," following that "consequently, no one knows the possibilities of translocation and the road communications within the boundaries of Russia so well as the managers of the shop-depots of the firm." He reiterated this statement in four consecutive paragraphs and followed by mentioning that the majority of the company's managers "untiringly take snapshots of interesting places, apparently from a commercial point of view."

This description of Singer's network would have certainly been familiar to Russians living in rural areas not accustomed to regular visits by outsiders. Furthermore, although the statement of Singer's familiarity with Russia's geography is clearly an attempt to build the case that the company held information that would be valuable to Germany in its war effort, a second element is equally important to this analysis. In the four paragraphs dedicated to organizational structure, Levitskii stated three times that Singer's managers continued to travel, regardless of the time of year. The fact that Levitskii saw this point to be worth reiterating suggests that he sought to emphasize the inherent differences between the rationalized operations of 
Singer and the rural life of most Russians. Because Russia's population consisted primarily of peasants whose lives were defined by seasons, drawing attention to the year-round operations of Singer's managers served to emphasize the foreign nature of the company. Here we once again see that the basis for Levitskii's claims of Singer's "Germanness" rests on highlighting a distribution network that was characteristic of modern capitalist enterprise.

Continuing on the theme of information, Levitskii focused on the company's data gathering practices, noting that Singer had been working to gather exact details concerning population density and harvests, as well as the general economic situation within the empire. In addressing what he depicted as an overly zealous desire to gather data about Russia, Levitskii tapped into suspicions about Singer that had much earlier roots. As in the American market, much of Singer's success in Russia had been a function of its willingness to finance its products and allow consumers to pay in installments, but the introduction of such programs into areas that had never encountered the concept of finance led to a great deal of confusion. Most relevant to the point at hand was the fact that many Russian peasants who purchased Singer's machines had never before been required to provide so much personal information to purchase a household good. Thus, in suggesting espionage as a possible reason for gathering this data, Levitskii proposed an answer to a question that likely puzzled many Russians. $^{24}$

To push this suspicion further, Levitskii claimed that Singer's top management had recently sent out a notice to lower managers, ordering them to supply the central office with the number of people making installment payments who had left to fight in the war, as well as information regarding the population at large. With these data, Levitskii claimed that Singer's employees could very easily use their mastery of mathematics to reach a conclusion about the total population of Russia who were mobilized in the war effort, assuring his readers that "the figure received will be within a few thousands of the actual figure.” In this case, we can see that Levitskii wished to stoke anxieties about both Singer's information gathering practices and the technological expertise held by those working in the firms.

24. Eric Lohr correctly states that Singer's data gathering was "one of the most important pieces of evidence" in the Russian military's growing suspicion of the company, hence reinforcing the importance of Singer's capitalist characteristics in these accusations. However, as Levitskii's comments suggest, the anxiety and suspicion aroused by Singer's data collection practices were already present in Russia prior to the military's investigation. This lends further support for the assertion that the military investigations in June served more to exacerbate pre-established suspicions than to generate new ones. (Lohr, War, 80). 
Levitskii then turned his attention from KS's relationship with its consumers to the internal workings of the company, noting that within KS there were "altogether ... strange and incomprehensible things." In particular, the company had the right to discharge employees at will "for the slightest delay or fulfillment of instructions ... no consideration being given to the length and faultlessness of their previous service or even to the disadvantage of such a discharge from a commercial point of view." Furthermore, he claimed that "[e]mployees discharged for old age and illness, although they may have given half of their lives to the service of the firm, have no right to and do not receive any assistance from the firm." Perhaps because this was an issue that hit close to home, Levitskii delivered his explanation of this practice with a particularly damning proclamation. "The discipline amongst the employees is not commercial," he explained, "but pure military-Prussian."

Here we can see that Levitskii was making a direct attempt to link the hierarchy characteristic of a modern enterprise to the rigid power structure of military discipline. This had the double effect of asserting that Singer's internal organization demonstrated evidence of a noncommercial influence at its highest levels, while simultaneously suggesting that this influence was a sign of the inherent military regimentation that many outsiders associated with German society. At the same time, in evoking the company's willingness to fire older and infirm employees with no future assistance, Levitskii was drawing another contrast between Russian society and Singer's business practices: Whereas the rural, family-based social networks that predominated in Russia at the time provided some security in times of illness and old age, contemporary corporations had no obligation to the worker beyond the employment period.

Only at this point, as the document reached its conclusion, did Levitskii put forward the assertion that what made the company German was not the company's business practices, but the actual presence of Germans in the company's management. Here, Levitskii explained that this power structure was directed at disadvantaging Russians vis-à-vis their superiors, which he claimed were overwhelmingly German. Levitskii then claimed that the aforementioned ruthless dismissal of workers applied only to KS's Russian workers, whom company officials referred to as "Russian pawns," and not its German employees, who, he claimed, regularly received quite handsome pensions for their service. Exaggerating the number of German employees, Levitskii claimed that, with the exception of agents and managers of small shops, "all the remaining employees of the firm up to and including the managing director and the members of the board are Germans and the majority of them German subjects." 
Overall, claims about Singer's German personnel made up only six sentences of his total letter, which, aside from the claims already mentioned, also alleged that some of Singer's German managers were shareholders in the firm. Here, he made specific reference to "the managing director," who, he claimed, was one of many Germans who continued to direct affairs through their assistants. He did not give a specific name, but it seems likely that his reference was aimed at Albert Flohr, to whom he had addressed his first letter.

Levitskii's final paragraphs, however, were particularly powerful in their claims. In addressing those who may not be convinced of Singer's German ties or malicious intent toward Russia, Levitskii stated:

If we allow that the German-Managers are ideal, honest persons, loving Russia with all their hearts and hating Germany, still we must acknowledge the fact that the information collected by them for commercial purposes is so valuable that it would tempt any person. You, whom it may concern, give serious attention to my remarks, investigate and decide: Is it possible to permit such a private organization in Russia during the time of war? At present, various districts have been occupied by the enemy and I am convinced that if it were necessary, the head offices of the firm could give such details and extensive information regarding these places as could in no wise be supplemented.

Thus, Levitskii's letter ended with an alarum about Singer's operations that was meant to appeal even to those who remained unconvinced of the company's German ties. These final sentences may be seen as somehow different from those that had suggested the longstanding malevolence of Singer's intentions, but they share the implication that Singer's basic operations made it a potential ally of the enemy. Free from the restraints of a national cause, Singer, as a "private organization," had no counterweight to the potential financial gains that selling its information could bring to the company. In this sense, the company, whatever its national origin, could not be trusted. This assertion was also particularly powerful as it could not be undone through any type of investigation into Singer's personnel or activities.

\section{Reaction to the Allegations}

As mentioned earlier, Singer's managers chose to ignore Levitskii's letter. As the war continued, however, they were faced with the reality that Levitskii's claims, whether through his efforts or those of others, 
gradually came to be leveled against the company by those with more influence than their former depot manager. On February 2, 1915, a tsarist decree deprived all citizens of enemy nations of the right to own rural land in Russia or to serve as directors or employees in any corporation that owned land in the Russian Empire. ${ }^{25}$ Because of the importance of the Russian market to Singer's international operations, its managers quickly moved to ensure that it was in compliance with the new Russian decrees. On February 5, three days after the Russian government passed this decree, Albert Flohr formally resigned his position and all of the company's German and Austrian employees were fired, thus ensuring that KS was operating within the bounds of the new Russian laws. ${ }^{26}$

Convincing others of this reality, however, was not so easily accomplished. Not long after the February 5 decree, Singer encountered the first significant manifestation of suspicion of its German ties. In late March 1915, the manager of KS's Petrograd central office, Oscar Kolpin, received a letter from Russian official Alexander Gouriev, stating that he was preparing a recommendation that the tsar increase government control over Singer's Russian operations on the grounds that Kolpin was "a direct subordinate of another German subject, Albert Flohr, Managing Director of the Company."27 Thus, despite the fact that Singer had already removed Flohr from its board, some Russians were unwilling to believe that his influence had so quickly vanished.

Having received no response to his letter, Gouriev made good on his word, and on April 3 the Russian government took control of the company. Shortly thereafter, a representative of the Ministry of Finance came to gather information regarding the validity of claims of German ownership in Singer. Having found no evidence to substantiate this claim, the representative certified that KS was indeed a Russian stock company with no ties to enemy countries. Nevertheless, Kolpin was arrested a few days later with no explanation.

At about the same time that the government established control over KS, the Russian press began printing claims that Singer was

25. Owen, Corporation, 182.

26. Notes from the first meeting of the Commission of Representatives of the All-Russian Zemstvo and Town Association, August 8, 1915, Box 155, Folder 1, Singer Manufacturing Company Records 1850-1975, Wisconsin Historical Society. It is interesting that in the minutes of this meeting, which will be further described later, Singer representatives made sure to emphasize that Flohr had a "stroke of paralysis" in 1905 that made it difficult for him to move.

27. A. Gouriev to Oscar Kolpin, March 24, 1915, Box 155, Folder 1, Singer Manufacturing Company Records 1850-1975, Wisconsin Historical Society. It is worth noting that this accusation is one that is made by Levitskii, making it possible that Gouriev was one of the recipients of Levitskii's letter. 
engaged in espionage for the German government. The company had little reason to speculate about the source of this concern; in an article printed in a Moscow area newspaper on April 5, 1915, the text of Levitskii's blackmail letter was printed almost in its entirety, excluding only Levitskii's claims about the dismissal of elderly or infirm Russian employees, parts of his introduction, and his attempts to undermine Singer's contributions to the war effort. ${ }^{28}$ This article, according to Singer's officials, sparked a series of similar articles and rumors across the empire that brought "the most serious of claims against the firm." 29

Levitskii's accusations against Singer were published the day after the government took control of Singer's Russian operations, and they could not have come at a worse time. In the same month, the German military shifted much of its attention onto the eastern front, which resulted in a series of German victories that pushed the Russian military out of Poland and Estonia, and pulled much of western Russia into the war zone. ${ }^{30}$ The panic that followed the German advance produced fertile soil for the seeds thrown by Levitskii and others, as Russians looked for an explanation for their sudden misfortune on the battlefield. This sparked anti-German riots in Moscow at the end of May that lasted for more than a week. ${ }^{31}$ However, whether because of the distance of Singer's factory from Moscow's center or because of its workers' awareness that it was not a German company, Singer reportedly saw no negative repercussions from these riots at the Podolsk factory.

The company's good fortune did not last, though. On June 6, the company found out that more than 200 of the company's offices in western Russia had been closed down after Russian military officials found the company in possession of information that they believed "had been or could be used for giving information to the enemy." 32 Although Singer's officials maintained that the data had been "accumulated for legitimate use in connection with [Singer's] business," the discovery that the company had indeed been gathering such data must have convinced those who had read Levitskii's letter that his

28. Article in No.24 of the Newspaper "Za Rossiu," April 5, 1915, Box 155, Folder 1, Singer Manufacturing Company Records 1850-1975, Wisconsin Historical Society. This article, like the preceding letter from Levitskii, is available in these archives only in a translation produced by Singer for its files.

29. Notes from the first meeting of the Commission of Representatives of the All-Russian Zemstvo and Town Association, August 8, 1915, Box 155, Folder 1, Singer Manufacturing Company Records 1850-1975, Wisconsin Historical Society.

30. Davies, Peacefully, 297.

31. Lohr, War, 31-54 passim.

32. Alexander to Buchanan, October 27, 1915, Box 155, Folder 1, Singer Manufacturing Company Records 1850-1975, Wisconsin Historical Society. 
accusations were grounded in fact. ${ }^{33}$ In the following months, things only got worse for Singer. By early August, more than 600 of the company's 2,000 Russian offices had been closed and some of its employees arrested without charge. Compounding these losses was that the military's actions against the company's offices served to substantiate claims of Singer's questionable alliances to those living in the district. Whether by sincere concern or simple opportunism, many of Singer's customers who were paying for their machines in installments chose to take this as an effective end to their financial obligations to the company. The loss of these payments represented a substantial portion of Singer's overall losses in Russia.

Singer's managers quickly took action to try and reverse the damage done to Singer's public image by engaging in acts that they believed would demonstrate the company's loyalty. First, the company began using its Russian-bound finances to purchase Russian bonds, which the leaders hoped would demonstrate their commitment to the Russian cause. Second, Singer's officials began to pursue government contracts, and specifically munitions orders. By playing a direct role in the war effort, Singer hoped to demonstrate its loyalty to the Russian government, and thus mitigate the damage done by Levitskii and others. ${ }^{34}$ Singer's managers also fruitlessly sought the assistance of the U.S. government, but officials in the American Embassy refused to take any substantial action on behalf of the firm, citing their desire to maintain neutrality in the war. On November 19, 1915, while on a trip to observe the company's European operations, Singer Vice President Douglas Alexander wrote to the New York office lamenting the lack of assistance from, and general ignorance shown by, American diplomatic personnel in Russia. "If we had got the right kind of backing through the Embassy the situation would never have got to the point of sequestration at all," he explained, perhaps exaggerating the Embassy's influence in the matter. ${ }^{35}$ In fact, by the end of 1915 , Singer's desperation led it so far

33. Ibid.

34. Davies, Peacefully, 304. Davies notes that this decision was also one of the only ways that Singer could get any substantial return on its investment.

35. Alexander to Park, November 19, 1915, Box 155, Folder 9, Singer Manufacturing Company Records 1850-1975, Wisconsin Historical Society. Alexander's overestimation of the embassy's influence speaks to Singer's general lack of engagement with the American government in its expansion into Russia and elsewhere across the globe. (Carstensen, Enterprise). In fact, relations between the United States and Russia had been on the decline since the 1890s and had become particularly cold after the United States abrogated the commercial treaty between the two countries in 1911 (Saul, War and Revolution; Owen, "Chukchi”). The shift in U.S.Russian relations came from increased competition between the two countries in Asia, as well as Americans' protest over the Russian government's mistreatment of Jews and other religious minorities. U.S. President Woodrow Wilson had long held a low opinion of the Russian government, and the position of U.S. ambassador to 
as to request the assistance of the British embassy. Despite appeals to the importance that Singer's factory played in maintaining Russia's war effort, British representatives informed Singer that the company was not within their sphere of influence. ${ }^{36}$

Initially, Singer's appeal to Russian officials seemed to have more promise. In response to Singer's proposal to equip its factory for the production of 3-inch and 6-inch shells, the Russian government asked that Singer demonstrate that all accusations of German involvement in the firm were false. For this purpose, the government formed a special commission to investigate all matters of the company's operations, and to conclude whether or not they should entertain Singer's proposal to produce munitions. Led by Prince Georgi Lvov, this commission, which included members of organizations such as the All-Russian Zemstvo and Town Associations, met on August 8, 1915, to decide Singer's fitness to undertake a service that was critical to the Russian war effort. ${ }^{37}$

Singer used its access to this influential audience to its advantage. It presented full documentation of its ownership and added a letter of support from U.S. Consul-General John Snodgrass confirming this point. Hoping to show that accusations of its German ties were no more than rumor, the head of the Podolsk factory, Walter Dixon, presented both Levitskii's letter and the newspaper article to the members of the commission as a means of discrediting accusations of espionage (which, according to both sides, had spread throughout the empire). ${ }^{38}$ In addition, the commission interviewed two Russian political officials from the Podolsk region, both of whom assured the commission that no one living in the vicinity had seen evidence of German activity in the factory. After hearing the evidence, the committee reconvened on August 10 and announced its conclusion that

Russia was held vacant for more than a year between 1913 and 1914 (Foglesong, Mission; Williams, Relations). In fact, Wilson had testified in favor of abrogating the U.S.-Russian Commercial Treaty while serving as governor of New Jersey in 1911. ("Address of Gov. Woodrow Wilson of New Jersey, Termination of the Treaty of 1832 Between The United States and Russia, Hearing Before the Committee on Foreign Affairs of the House of Representatives, Monday, December 11, 1911. Washington, DC: U.S. Government Printing Office, 1911, p. 15).

36. Alexander to Buchanan, November 3, 1915, Box 155, Folder 1, Singer Manufacturing Company Records 1850-1975, Wisconsin Historical Society.

37. Notes from the first meeting of the Commission of Representatives of the All-Russian Zemstvo and Town Association, August 8, 1915, Box 155, Folder 1, Singer Manufacturing Company Records 1850-1975, Wisconsin Historical Society.

38. Ibid. Although the representatives of the Russian government only generally acknowledged the rumors in Russian newspapers, Dixon stated at the trial that "[e]xtracts from the article were copied into many newspapers and served as the basis for a whole series of articles and remarks bringing the most serious accusations against the firm." 
the company was in no way associated with the enemy powers. ${ }^{39}$ Even better, the investigation praised the Podolsk factory, recommended that government supervision be reconsidered, and ordered that the commission's findings be directed toward ending the persecution of Singer. ${ }^{40}$

Despite the fact that Singer's officials received news on the same day that their offices in Kiev had been sequestered, they nonetheless must have felt that Singer was reaching the end of its problems in Russia. But to convince the leadership of an under-industrialized country in the midst of war allow one the most technologically advanced factories within its borders to produce weapons for its military is a much easier task than curbing the patriotic tendencies of a population enduring the stresses that come with popular mobilization. Throughout 1915, governors as far away as eastern Siberia requested the right to act against Singer's offices in their regions, drawing on local press stories about Singer's espionage as justification. On September 10, the governor of Kazan made a similar request, noting his belief that a failure to do so could spark riots. ${ }^{41}$

The commission meeting did not signal an end to Singer's troubles in Moscow either; when Singer's Podolsk factory was converted for the purposes of making munitions, the Russian government's incentive to supervise Singer's operations only increased. In October 1915, Singer's officials found out that several of its central office agents had been arrested and imprisoned, and that five new government controllers might possibly be added to oversee the company. ${ }^{42}$ With these state representatives in full control of Singer's operations, it is no surprise that production for the government's needs became a major activity of the company, and by January 1916, 86 percent of the business done by the Podolsk factory was under government contract. ${ }^{43}$ Although the company's offices were nominally returned to Singer by the end of 1915, local army and police officials who remained suspicious of the company often complicated Singer's activities. ${ }^{44}$ Tsarist oversight of Singer's operations continued until the regime fell and was replaced by a provisional government in February 1917, but in the meantime the company saw Russia transformed from Singer's most promising market into a liability in fewer than three years.

39. Notes from the second meeting of the Commission of Representatives of the All-Russian Zemstvo and Town Association, August 10, 1915, Box 155, Folder 1, Singer Manufacturing Company Records 1850-1975, Wisconsin Historical Society.

40. Ibid.

41. Lohr, War, 80.

42. Alexander to New York Office, October 1915, Box 155, Folder 1, Singer Manufacturing Company Records 1850-1975, Wisconsin Historical Society.

43. Davies, Peacefully, 304.

44. Lohr, War, 81. 
Making matters worse, the refusal of government controllers to allow Singer to use its Russian funds for the purchase and importation of necessary materials meant that to continue operating, KS began taking loans from its American parent corporation, deepening the firm's losses. The establishment of the provisional government brought some hope to Singer's managers, but the continuation of laws preventing the exportation of Russian funds, as well as the continuing war effort, prevented the company from fully recovering. As late as March 1917, the American consul in Petrograd reported that the company's headquarters remained a subject of suspicion due to "the masses believing the Singer Co. to be a German corporation." ${ }^{45}$ Having lost nearly all hope in the future of KS, Singer's managers rented their Podolsk factory to the provisional government for the continued production of munitions. When the Soviet government finally nationalized the company's possessions following the October Revolution of 1917, Singer's losses in Russia were complete.

\section{Conclusion}

In looking at the series of events that led Russians to believe that Singer was a German company, it seems clear that the most important evidence was not the company's German employees (which were few), nor its ties to the German government (which did not exist), but the nature of the company's operations. These features, such as the collection of data, the company's sales practices, its presence across the empire, and its mobility, would have been recognized as pioneering techniques by those working within Singer or many other capitalist enterprises, but were seen as confusing or suspicious to a Russian population that had never before encountered them. Under the pressures of World War I, the possibility of espionage presented a unified explanation for these behaviors that led Russians of various social and geographic positions to mobilize against the company.

Seen through this lens, we can understand why popular suspicion of Singer persisted even after military raids on its offices and state investigations into the origin of the firm and its employees failed to produce any substantial evidence to support accusations against the company. To Singer's top managers, disproving allegations of

45. The Consul at Petrograd (Winship) to the Secretary of State, March 20, 1917, Papers Relating to the of the United States, 1918. Russia. Volume 1. United States Department of State. Washington, DC: U.S. Government Printing Office, 1918, p. 8; http://digital.library.wisc.edu/1711.dl/FRUS.FRUS1918v1. Last accessed June 1, 2015. 
German ties meant demonstrating that the company's personnel were not German and that the company was wholly owned by non-enemy nationals. However, as Levitskii's letter shows, the presence of German employees was just one of several pieces of evidence that could prove that Singer was German. Thus, in the minds of many Russians, the elimination of all German personnel was not tantamount to the elimination of all German influence. As a result, Singer once again lived up to its reputation as a pioneering enterprise by becoming among the first companies to fall victim to anti-capitalism on Russian soil.

In reflecting on Singer's experiences in World War I-era Russia, a few observations are worth highlighting. First, because the company entered foreign markets without the assistance of either the U.S. or local governments, its management lacked the established relationships that could have elicited more meaningful action on its behalf. Thus, Singer's choice of entry mode, though rational in the 1890s, proved to be a major liability following the outbreak of World War I. Had the company selected a joint venture with local elites, Russians' concerns over the company's loyalties might have been mitigated. After all, demonstrating that the firm was owned by Russians, and not simply by non-German foreigners, would have helped build a much greater shield against many of the allegations the company faced.

A second point worth addressing is that Singer's accusers did not draw on the powerful forces of anti-Semitism that existed within the Russian Empire both before and during World War I. Although many of the firm's activities detailed by Levitskii may appear to strike an anti-Semitic chord, at no point does the firm seem to have been cast as a Jewish operation. This is likely because the Russian Empire's confinement of Jews to specific regions, as well as the strict limitations on Jewish participation in the economy, meant that ethnic Germans filled the roles of financial intermediaries and merchants that were commonly held by Jewish residents elsewhere in Europe. As Yuri Slezkine has done well to point out, the persecution of Jewish communities in Europe was part of a greater prejudice against what he calls Mercurian peoples, whose position as permanent outsider made them an object of suspicion for the Apollonian peoples (ethnic/ national majorities) of a specific region. ${ }^{46}$ Furthermore, it seems unlikely

46. Slezkine, Century. Slezkine presents the history of the world as the interaction of two particular types of people: (1) Apollonian peoples, whose existence is tied to a claim of land and based on productive labor, and (2) Mercurian peoples, whose existence was transitory, and livelihood was based on nonproductive labor such as trade. Whereas ethnic Germans who lived in Germanic parts of Europe would be considered Apollonian, communities of ethnic Germans who had long lived in Russia acted as Mercurian peoples in Russian society in the nineteenth and early twentieth centuries. 
that S. Levitskii, who had a Jewish last name himself, would have crafted a narrative of Singer's malevolence if he perceived that the backlash may have been detrimental to his own plight in Russia.

In terms of our understanding of Russian history and the history of capitalism, Singer's plight during World War I helps to build on Thomas Owen's recent observation that the overt animosity toward capitalism shown by the leaders of the Soviet regime did not represent a clear break with the past, but rather tapped into prejudices and fears that had developed in previous decades. ${ }^{47}$ As shown above, Levitskii's evidence of Singer's "Germanness" was based more on behavior than ethnicity. Although the nationally defined enemy of Levitskii's letter and the class-defined enemy of Bolshevism may have come from very different ideological perspectives, both enemies behaved in similar ways and worked against the interests of Russian society. Thus, the transition from fighting Germans during World War I to fighting capitalists during the Russian Civil War (1918-1921) may have been a smoother one for many Russians than we have previously recognized.

Finally, the story told here allows us to place twenty-first-century concerns over private data collection into its historical context. Although the development of the Internet and computer technology have allowed modern companies to amass far more data on their consumers than one could have imagined in the early twentieth century, today's executives at companies such as Google and Sony face a problem that is similar to those faced by Singer's managers a century earlier. Much like their Russian counterparts in the late-tsarist era, today's consumers are often perplexed and concerned as to why private organizations would want to collect seemingly mundane details about their lives. Far from being the product of the Internet age, the concern surrounding private collection of personal data here appears as an inherent by-product of modern capitalism that is likely to last as long as the economic system that produces it.

\section{Bibliography of Works Cited}

\section{Books}

Calder, Lindol. Financing the American Dream: A Cultural History of Credit. Princeton, NJ: Princeton University Press, 1999.

Carstensen, Fred. American Enterprise in Foreign Markets: Studies of Singer and International Harvester in Imperial Russia. Chapel Hill: University of North Carolina Press, 1984.

47. Owen, "Chukchi." 
Davies, Robert Bruce. Peacefully Working to Conquer the World: Singer Sewing Machines in Foreign Markets, 1854-1920. New York: Arno Press, 1976.

Foglesong, David S. The American Mission and the "Evil Empire": The Crusade for a "Free Russia" Since 1881. Oxford: Oxford University Press, 2007.

Fuller, William C., Jr. The Foe Within: Fantasies of Treason and the End of Imperial Russia. Ithaca, NY: Cornell University Press, 2006.

Gatrell, Peter. Russia's First World War: A Social and Economic History. Harlow, UK: Pearson Longman, 2005.

Lohr, Eric. Nationalizing the Russian Empire: The Campaign against Enemy Aliens during World War I. Cambridge, MA: Harvard University Press, 2003.

Owen, Thomas C. The Corporation under Russian Law, 1800-1917: A Study in Tsarist Economic Policy. Cambridge: Cambridge University Press, 1991.

Ruane, Christine. The Empire's New Clothes: A History of the Russian Fashion Industry, 1700-1917. New Haven, CT: Yale University Press, 2009.

Saul, Norman E. War and Revolution: The United States and Russia, 19141921. Lawrence: University Press of Kansas, 2001.

Slezkine, Yuri, The Jewish Century. Princeton, NJ: Princeton University Press, 2004.

Williams, William Appleman. American Russian Relations, 1781-1947. New York: Rinehart \& Co., 1952.

\section{Articles}

Carstensen, Fred V. and Richard Hume Werking. "International Harvester in Russia: The Washington- St. Petersburg Connection.” The Business History Review 57, no. 3 (1983): 347-366.

Davies, Robert Bruce. "'Peacefully Working to Conquer the World': The Singer Manufacturing Company in Foreign Markets, 1854-1889." Business History Review 46, no. 3 (1969): 299-325.

Domosh, Mona. "Uncovering the Friction of Globalization: American Commercial Embeddedness and Landscape in Revolutionary-Era Russia." Annals of the American Association of American Geographers 100, no. 2 (2010): 427-443.

Godley, Andrew. "Entrepreneurial Opportunities, Implicit Contracts, and Market Making for Complex Consumer Goods.” Strategic Entrepreneurial Journal 7 (2013): 273-287.

—. "Selling the Sewing Machine Around the World: Singer's International Marketing Strategies, 1850-1920.” Enterprise \& Society 7, no. 2 (2006): 266-314.

_. "The Global Diffusion of the Sewing Machine, 1850-1914." Research in Economic History 20 (2001): 1-45.

Hill, Charles W., Peter Hwang, and W. Chan Kim. "An Eclectic Theory of the Choice of International Entry Mode." Strategic Management Journal 11, no. 2 (1990): 117-128.

Owen, Thomas C. "Chukchi Gold: American Enterprise and Russian Xenophobia in the Northeastern Siberia Company." Pacific Historical Review 77, no. 1 (2008): 49-85. 
Slangen, Arjen H. L., and Rob H. M. van Tulder "Cultural Distance, Political Risk, or Governance Quality? Towards a More Accurate Conceptualization and Measurement of External Uncertainty in Foreign Entry Mode Research.” International Business Review 18 (2009): 276-291.

\section{Primary Sources}

Papers Relating to the Foreign Relations of the United States, 1918. Russia. Volume 1. United States Department of State. Washington, DC: U.S. Government Printing Office, 1918.

Singer Manufacturing Company Records, 1850-1975. Wisconsin Historical Society, Madison, WI.

State Archives of the Russian Federation, Moscow, Russian Federation. Fond 494, Finnish Gendarmerie.

Termination of the Treaty of 1832 Between The United States and Russia, Hearing Before the Committee on Foreign Affairs of the House of Representatives, Monday, December 11, 1911. Washington, DC: U.S. Government Printing Office, 1911. 